Науковий вісник НЛтУ України
Scientific Bulletin of UNFU
https://nv.nltu.edu.ua
https://doi.org/10.15421/40280618
Article received 15.06.2018 p.
Article accepted 25.06.2018 p.
Удк 351.861

С. В.Жартовський

Украӥнський науково-дослідний інститут иүивільного захисту, м. Київ, Украӥна

\title{
ВИКОРИСТАННЯ СОЛЕЙ ПОЛІГЕКСАМЕТИЛЕНГУАНІДИНУ В СКЛАДАХ ВОДНИХ ВОГНЕГАСНИХ РЕЧОВИН ДЛЯ ПРОТИПОЖЕЖНОГО ЗАХИСТУ ОБ'ЄКТІВ ІЗ ЦЕЛЮЛОЗОВМІСНИХ МАТЕРІАЛІВ
}

\begin{abstract}
Обгрунтовано актуальність створення складів екологічно безпечних водних вогнегасних речовин для активного протипожежного захисту об'єктів. Визначено особливу вразливість об'єктів із пожежним навантаженням, сформованим завдяки целюлозовмісним матеріалам (деревині, тканинам, паперу, очерету тощо), оскільки вони здатні займатись навіть від малокалорійних джерел. На основі аналізу практики розроблення водних вогнегасних речовин визначено перспективність додавання до води різних інгредієнтів для покращення іiї вогнегасної дії, зокрема для надання інгібувальних властивостей. 3'ясовано, що позитивний досвід від використання солей полігексаметиленгуанідину в складах водних вогнебіозахисних речовин для пасивного вогнезахисту целюлозовмісних матеріалів доцільно використати і під час розроблення складів водних вогнегасних речовин для активного протипожежного захисту об'єктів. Експериментальними дослідженнями за стандартними методиками показано, що додавання до води комплексної сполуки полігексаметиленгуанідингідрофосфат карбаміду в концентрації до 3 \% призводить до збільшення дальності струменя водяного вогнегасника BВ-9 не менше ніж на 10 \%, при цьому час викиду вогнегасної речовини з вогнегасника і час гасіння модельного вогнища пожежі 1А скорочується не менше ніж на $15 \%$. За оригінальними методиками визначено, що використання водної вогнегасної речовини ФСГ-2М під час гасіння модельних вогнищ пожежі класу А майже в 5 разів ефективніше, порівняно з водою, а під час гасіння модельних вогнищ пожежі класу В - більше ніж у 3 рази. Полігонними випробуваннями та лабораторними дослідженнями розкрито феномен унеможливлення повторного займання пожежного навантаження, сформованого деревиною, використовуючи для гасіння речовини ФСГ-2М.
\end{abstract}

Ключові слова: водні вогнебіозахисні речовини; активний протипожежний захист.

Вступ. Аналіз статистики пожеж свідчить про те, що значна кількість пожеж характеризується тим, що основними горючими матеріалами, що формують пожежне навантаження об'єкта, є целюлозовмісні матеріали (деревина, тканини, папір, очерет тощо), які здатні займатись навіть від малокалорійних джерел. Кількість загиблих людей у цих випадках становить до 90 \% від загального кількості загиблих людей на пожежах (Baratov \& Molchadskyi, 2011). Ця тенденція зберігається, оскільки популярність використання екологічних целюлозовмісних матеріалів (ЦВМ) у будівництві дедалі зростає. Оскільки ЦВМ зазвичай $є$ легкозаймистими матеріалами, об'єкти 3 таким пожежним навантаженням можуть ставати надзвичайно вразливими в умовах сьогодення, коли значно зросла ймовірність терористичних атак. Тому дуже часто об'єкти 3 масовим перебуванням людей, конструкції яких виконано 3 деревини, відносять до критичної інфраструктури, що потребує особливого режиму захисту (Muresan \& Caceu, 2010).

Ефективність активного протипожежного захисту об'єкта (використання вогнегасної техніки та речовин) значною мірою залежить від якості вогнегасних речо- вин та технології їх застосування. До сучасних вогнегасних речовин належать водні вогнегасні речовини, піноутворювачі загального та спеціального призначення, газові вогнегасні речовини, вогнегасні порошки, аерозолеві вогнегасні речовини (Antonov et al., 2004). Ocновною складовою водних вогнегасних речовин (BВР) $\epsilon$ вода. Вода - найпоширеніша вогнегасна речовина, яка характеризується високою питомою теплоємністю, прихованою теплотою пароутворення, вона хімічно інертна відносно більшості горючих речовин і матеріалів, доступна і дешева.

Використання води $\epsilon$ надійним і ефективним під час гасіння пожеж, що пов'язано з горінням речовин і матеріалів у всіх трьох агрегатних станах (твердому, рідкому, газоподібному). Однак під час гасіння водою, через недосконалість техніки подачі та розпилення води, а також внаслідок інших причин, здебільшого не реалізуються всі її унікальні фізичні та фізико-хімічні властивості. У пожежній справі воду застосовують без добавок або з добавками, формуючі компактні, розпилені (середній діаметр краплин понад 100 мкм) і тонко розпилені (середній діаметр краплин до 100 мкм) струмені

Інформація про авторів:

Жартовський Сергій Володимирович, канд. техн. наук, ст. наук. співробітник, провідний науковий співробітник науководослідного центру. Email: zhart20@ukr.net

Цитування за ДСТУ: Жартовський С. В. Використання солей полігексаметиленгуанідину в складах водних вогнегасних речовин для протипожежного захисту об'єктів із целюлозовмісних матеріалів. Науковий вісник НлтУ України. 2018, т. 28, № 6. С. 93-98.

Citation APA: Zhartovskyi, S. V. (2018). The use of polyhexamethyleneguanidine salts in the formulations of water-based fireextinguishing agents for fire safety of objects made of cellulose-containing materials. Scientific Bulletin of UNFU, 28(6), 93-98. https://doi.org/10.15421/40280618 
(Antonov et al., 2004). Часто-густо як домішки використовують речовини, які можуть істотно негативно впливати на довкілля. Тому розвинені країни встановлюють певні обмеження на концентрації шкідливих речовин у складах ВBP (Standardization Administration of China, 2006, 208; NFPA, 2011; Yang Liang, 2015). При чому вимоги стандартів, якими керуються у США, Свропі та Китаї, не завжди тотожні (Yang Liang, 2015).

Перспективним напрямом $є$ розроблення і застосування гелеутворювальних систем (ГУС) для запобігання, локалізації та ліквідації пожеж і загорянь (Kireev \& Babenko, 2002). У роботах (Bilkun et al., 1983; Kireev, Zhernoklev \& Savchenko, 2005) відзначено можливість використання зазначених композицій для вогнезахисту деревини. Системи, які містять водорозчинний полімер і неорганічну сіль, або водорозчинний полімер і змочувач, мало відрізняються від розчинів полімерів. Показано, що у випадку застосування потрійної композиції (водорозчинний полімер, неорганічна сіль і змочувач) зразки деревини майже втрачають здатність до займання. Необхідно відзначити обмеженість концентрації неорганічної солі в зазначеній композиції, оскільки проявляється здатність до висолювання водорозчинного полімеру або його коагуляції (Bilkun et al., 1982), що стримує використання таких композицій в пожежній техніці.

У практиці пасивного (профілактичного) протипожежного захисту ЦВМ широко використовують водні вогнебіозахисні речовини (ВВБЗР), але інформації щодо прямого використання ВВБЗР як вогнегасних речовин не виявлено. Водночас наведений аналіз щодо розроблення ВВР свідчить про перспективність додавання до води різних інгредієнтів для покращення її вогнегасної дії, зокрема для надання інгібувальних властивостей. Подібні інгредієнти можуть бути в складах ВВБЗР.

Метою роботи є дослідження можливості створення ВВБЗР, які доцільно використати як заряди для засобів пожежогасіння (ВВР), що сприятиме створенню єдиної системи пасивного й активного протипожежного захисту об'єкта 3 пожежним навантаженням, сформованим за рахунок ЦВМ.

Викладення основного матеріалу дослідження. Після вивчення властивостей полігексаметиленгуанідингідрофосфат карбаміду (ПГМГФК) визначено, що йому притаманні властивості, характерні для поверхнево-активних речовин (Zhartovskyi, 2012), а водні розчини за концентрації ПГМГФ більше 50 \% здатні утворювати гідрогель. Ці властивості є корисними щодо пожежогасіння ВВР. На основі комплексної сполуки ПГМГФК науковці ТОВ "Захист-Центр" (м. Київ) створили ВВР (ВВБЗР) ФСГ-2М.

Проведені дослідження 3 визначення впливу концентрації ПГМГФК (молекулярна маса ПГМГФ більше 9000 в.о.) у водному розчині на ефективність гасіння пожежі класу А з використанням вогнегасника ВB-9. Визначення довжини струменя та тривалість гасіння водної вогнегасної речовини проводили згідно з (DSTU 3675-98, 1999). Випробування проводили на відкритому, спеціально обладнаному майданчику, розташованому в захищеному від вітру місці за температури навколишнього середовища $20^{ \pm 5}{ }^{\circ} \mathrm{C}$. Довжину струменя визначали мірною рейкою. Також використовували контрольну розмітку стіни, темного кольору (DSTU 367598, 1999). Результати досліджень із визначення довжи- ни струменя (L), залежно від концентрації ПГМГФК, представлено на рис. 1.

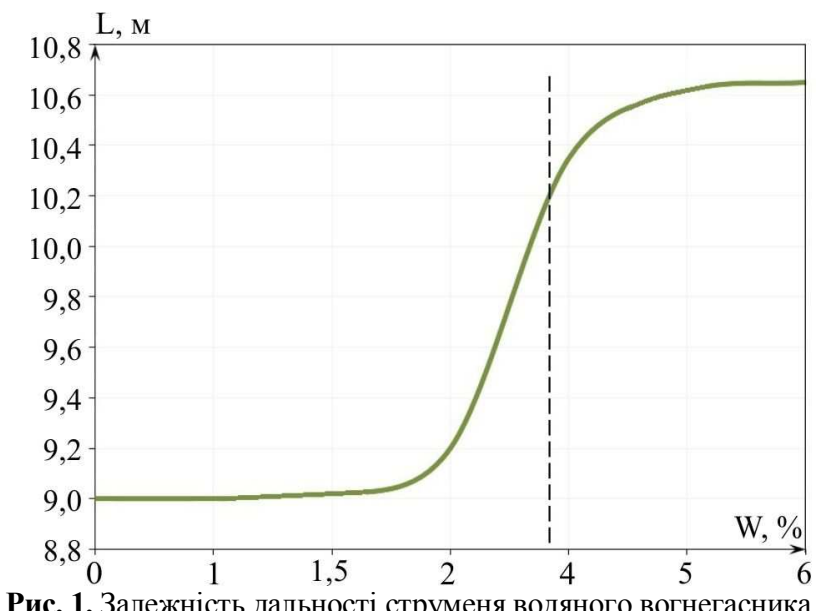

Рис. 1. Залежність дальності струменя водяного вогнегасника BВ-9 від концентрації ПГМГФК

Згідно з технічними характеристиками водного вогнегасника ВВ-9, дальність струменя під час використання водної вогнегасної речовини води становить 68 м. Як видно з рис. 1, дальність струменя під час використання $2 \%$-водного розчину ПГМГФК зростає більше 9 м, а наявність в розчині 3-4 \% цієї речовини призводить до зростання дальності струменя більше 10 м. Такий результат пов'язаний 3 конформаційними змінами в молекулі ПГМГФК, що дає змогу молекулі ПГМГФК під час руху орієнтуватися переважно вздовж потоку, оскільки в області концентрації (приблизно від 1,0 до 3,0-5,0 мас.\%) відбуваються конформаційні зміни в макромолекулах ПГМГФК, а саме: макромолекули приймають все більш розгорнуту конформацію (Nyzhnyk \& Nyzhnyk, 2009).

Згідно $з$ технічними характеристиками водних вогнегасників, час викиду заряду вогнегасника ВВ-9 становить 45 с. Важливо дослідити, як впливатиме наявність невеликих концентрацій ПГМГФК (до 5 \%) на час викиду заряду.

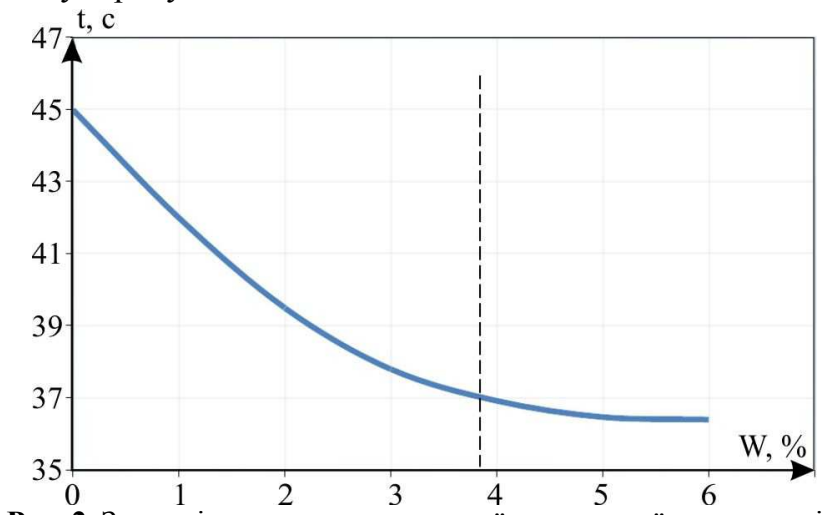

Рис. 2. Залежність часу викиду водної вогнегасної речовини від концентрації ПГМГФК

На рис. 2 представлено залежність часу викиду водної вогнегасної речовини від концентрації ПГМГФК, яка підтверджує гіпотезу про поліпшення текучості води (вода 3 добавками полімерних речовин), завдяки яким зменшується гідравлічний опір і турбулентність потоків (Moiseenko \& Dubkov, 1982). Дослідження тривалості гасіння, залежно від концентрації ПГМГФ, проводили на модельному осередку пожежі класу 1А. Це штабель $з$ дерев'яних брусків із поперечним перерізом у вигляді квадрату зі стороною 40 мм. 
Для виготовлення модельних осередків використовували заготовки деревини із сосни звичайної відповідно до вологості від $10 \%$ до 14 \%. Бруски, що утворюють поверхневі грані штабеля, для міцності закріплювали скобами. Штабель розміщували на двох сталевих кутиках встановлених на жорстких металевих опорах. Бруски кожного наступного шару клали перпендикулярно до брусків шару, що знаходиться нижче так, щоб при цьому утворювалися канали прямокутного перерізу по всьому об'єму. Форма штабеля повинна наближатися до кубу. Деко відповідного розміру розміщували на підлозі (платформі) під штабелем. Виставляли деко горизонтально, дно його покривали шаром води як базою і заливали бензин А-76 у кількості 1,1 л. Підпалювали пальне. Після вигоряння пального деко забирали 3-під штабеля. Вільне горіння модельного осередку продов-

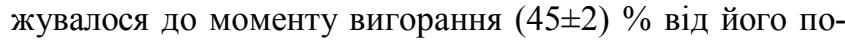
чаткової маси, після чого розпочинали гасіння.

3 відстані не менше 1,8 м спрямовували струмінь вогнегасної речовини на фронтальну поверхню модельного осередку. Продовжували гасіння з меншої відстані, спрямовуючи струмінь на верхню, нижню і бічну поверхні (за винятком тильної поверхні осередку).

Залежність тривалості гасіння модельного вогнища 1А від концентрації ПГМГФК наведено на рис. 3.

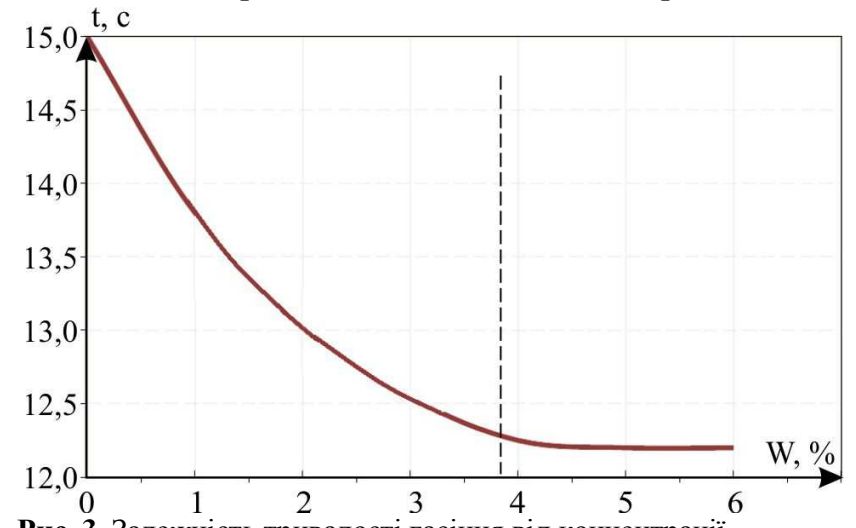

Рис. 3. Залежність тривалості гасіння від концентрації ПГМГФК

Як видно 3 рис. 3, тривалість гасіння під час використання води становить 15 с. Використовуючи як водну вогнегасну речовину ФСГ-2М, це значення знижується до 12 с.

Вогнегасну ефективність ФСГ-2М під час гасіння модельних вогнищ класу А визначали за методикою, що розроблено в УкрНДІЦЗ. Сутність методики полягає у визначенні вогнегасної ефективності досліджуваних водних вогнегасних речовин за рахунок визначення їх маси, яку необхідно подати, за однакових умов, на гасіння вогнища пожежі класу А тонкорозпиленими струменями. Відносну вогнегасну ефективність $(\mathrm{Z})$ досліджуваних водних вогнегасних речовин визначали порівняно з вогнегасною ефективністю води.

Для розрахунку показника відносної вогнегасної ефективності кожної водної вогнегасної речовини, що досліджували, використовували середнє арифметичне значення величини $\Delta \mathrm{m}$, що було отримано внаслідок проведення трьох дослідів для кожного виду водної вогнегасної речовини. Під час проведення досліджень використовували водні вогнегасні речовини різного хімічного складу, які впливають на процес вогнегасіння модельного вогнища пожежі класу А. Результати проведених експериментальних досліджень 3 визначення відносної вогнегасної здатності водних вогнегасних речовин навели в табл. 1.

Табл. 1. Усереднені результати визначення відносної вогнегасної здатності тонкорозпилених струменів деяких водних вогнегасних речовин (клас пожежі - A, час вільного горіння - 300 с, площа горіння - $0,2268 \mathrm{~m}^{2}$ )

\begin{tabular}{|c|c|c|c|}
\hline $\begin{array}{l}\text { Вогнегасна } \\
\text { речовина }\end{array}$ & $\begin{array}{c}\text { Вміст } \\
\text { добавки } \\
\text { до во- } \\
\text { ди, \% } \\
\text { мас }\end{array}$ & $\begin{array}{c}\text { Середня маса вог- } \\
\text { негасної речови- } \\
\text { ни, витраченої на } \\
\text { гасіння, кг }\end{array}$ & $\begin{array}{c}\text { Відносна вог- } \\
\text { негасна здат- } \\
\text { ність вогнегас- } \\
\text { ної речовини }\end{array}$ \\
\hline Вода & - & $5 \pm$ & 1,00 \\
\hline $\begin{array}{c}\text { Вода }+2 \% \text { ПУ } \\
\text { типу Pirena }\end{array}$ & 2 & $3 \pm$ & 1,66 \\
\hline $\begin{array}{c}\text { Вода }+2 \% \\
\text { ГУС Prevento }\end{array}$ & 2 & $1,6 \pm$ & 3,10 \\
\hline $\begin{array}{c}\text { Вода }+34 \% \\
\mathrm{~K}_{2} \mathrm{CO}_{3}+0,5 \% \\
\text { ПУ типу AFFF }\end{array}$ & $34 / 0,5$ & $1,2 \pm$ & 4,16 \\
\hline $\begin{array}{c}\text { ВВБЗР ФСГ- } \\
\text { 2M } \\
\end{array}$ & 32 & $1,0 \pm$ & 4,93 \\
\hline
\end{tabular}

BВР $з 2$ \% гелеутворювальної речовини типу Prevento збільшує iii вогнегасну здатність для пожеж класу А більш ніж у 3 рази. Підвищення вогнегасної здатності водної вогнегасної речовини можна пояснити тим, що під час гасіння пожежі збільшується кількість чинників, що забезпечують припинення горіння. Основу такої речовини становить вода, тому на першому етапі головним чином проявляється охолоджувальна дія. Під час нагрівання починається процес випаровування води 3 гелеутворювальної речовини. Одночасно відбувається розведення зони горіння водяною парою. Після подальшого нагрівання на поверхні деревини утворюється ксерогель, який чинить теплоізолюючу дію. Оскільки процес гелеутворення сповільнює стікання вогнегасної речовини 3 вертикальних та похилих поверхонь, що сприяє загальному підвищенню ефективності вогнегасної дії.

Додавання до води інгібувальних добавок максимально підвищує вогнегасну здатність. Наочно це показує результат додавання до води інгібувальної солі, а також піноутворювача типу AFFF (вогнегасна здатність збільшується у 4,16 раза). Найкращі результати були отримані під час застосування ВВБЗР ФСГ-2М, відносна вогнегасна здатність якої становить 4,93, тобто вона майже в 5 разів ефективніша за воду.

Вогнегасну ефективність ФСГ-2М під час гасіння модельних вогнищ класу В проводили на установці за методикою, що розроблена в УкрНДІЦЗ. Методика призначена для визначення показника відносної вогнегасної ефективності водних вогнегасних речовин для гасіння вогнищ класу В з використанням тонкорозпилених струменів, а також впливу на його значення хімічного складу та концентрації активних добавок до води.

Випробування проводили в лабораторних умовах у витяжній шафі з примусовою вентиляцією. Попередні випробування проводять на дистильованій воді. При цьому підбирають умови подавання: мінімальний робочий тиск і висоту подавання розпиленої води, коли досягається гасіння дека визначеного діаметра.

Подальші випробування досліджуваних водних вогнегасних речовин проводять за цими параметрами, дотримуючись однакових умов гасіння.

Визначають витрату вогнегасної речовини ваговим методом, зібравши тонкорозпилений розчин до попередньо зваженої посудини впродовж визначеного проміжку часу у трьох паралельних дослідах. 
Витрату вогнегасної речовини (води, ВВБЗР ФСГ$2 \mathrm{M})$ за одиницю часу $\mathrm{R}\left(\mathrm{cm}^{3} / \mathrm{c}\right)$ визначають за формулою

$$
\mathrm{R}=\frac{m_{1}-m_{0}}{\tau \rho},
$$

де: $m_{0}$ - маса посудини для збирання розпиленої вогнегасної речовини, г; $m_{1}-$ маса посудини для збирання розпиленої вогнегасної речовини зі зібраною речовиною, г; $\tau$ - час збирання вогнегасної речовини, с; $\rho$ густина досліджуваної вогнегасної речовини, г $/ \mathrm{cm}^{3}$.

За результат визначення показника витрати вогнегасної речовини беруть середнє арифметичне трьох результатів випробувань. Максимальне відхилення результатів визначення, одержаних одним оператором за однакових умов, від середнього арифметичного значення не повинне перевищувати $5 \%$.

Розраховують критичну інтенсивність подавання ВВБЗР ФСГ-2М, за якої досягають гасіння:

$$
\text { I } \kappa p=\frac{R}{S}, \mathrm{~cm}^{3} \mathrm{c}^{-1} \mathrm{M}^{-2},
$$

де $S$ - площа дека.

Показник відносної вогнегасної ефективності вогнегасної речовини визначають за формулою

$$
\kappa=\frac{I \kappa p H_{2} O}{I \kappa p B B P},
$$

де: Ікр $\mathrm{H}_{2} \mathrm{O}$ - критична інтенсивність подавання води, $\mathrm{cm}^{3} \mathrm{c}^{-1} \mathrm{M}^{-2} ;$ IкрBBP - критична інтенсивність подавання водної вогнегасної речовини, $\mathrm{cm}^{3} \mathrm{c}^{-1} \mathrm{M}^{-2}$.

Результати досліджень представили на рис. 4.

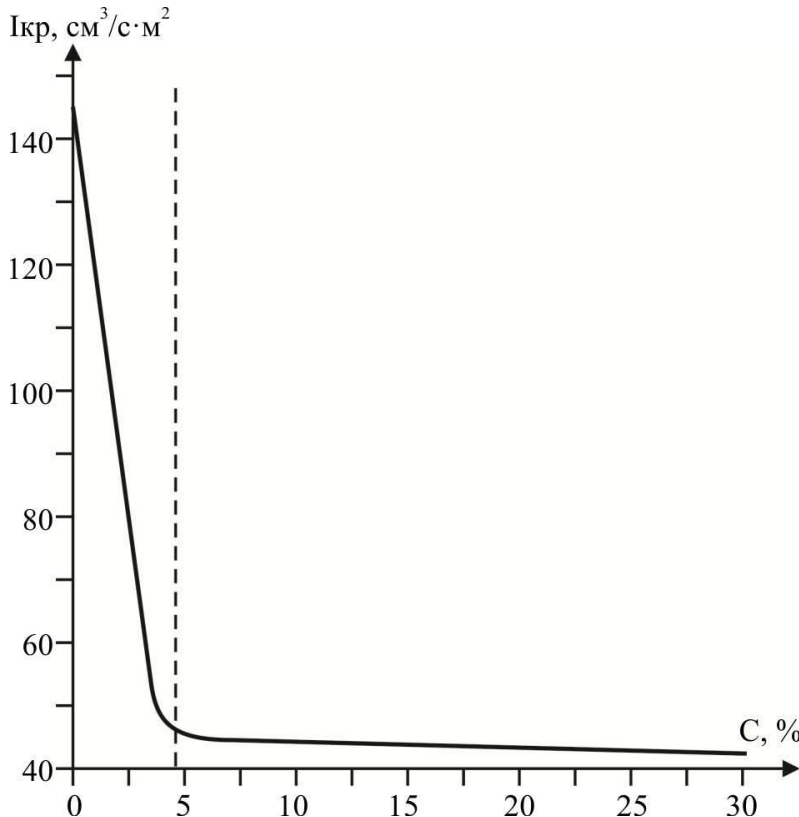

Рис. 4. Залежність критичної інтенсивності подавання ВВБЗР на гасіння вогнища класу В від концентрації активної речовини (ПГМГФК + 0,2 \% S. F. Р. М.) у складі ВВБЗР ФСГ-2М

Під час гасіння спостерігали такий феномен: коли ВВБЗР ФСГ-2М попадає на поверхню горючої речовини, вона не занурюється, а змочує її, утворюючи плівку, яка витискує полум'я до борту деко, з подальшим гасінням горючої рідини. 3 рис. 4 видно, що для гасіння горючої рідини водою необхідно, щоб Ікр досягло значення $145 \mathrm{~cm}^{3} /\left(\mathrm{c} \cdot \mathrm{M}^{2}\right)$, а Ікр для ВВБЗР ФСГ-2М достатньо

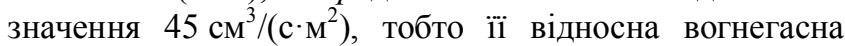
здатність у 3,21 раза більша.
Також проведені полігонні порівняльні випробування заряду ВВР ФСГ-2М та заряду $6 \%$ водного розчину піноутворювача S. F. Р. М. Сутність методу випробувань полягала у визначенні маси водної вогнегасної речовини, яка витрачається на одиницю відкритої поверхні горіння вогнища пожежі класу А максимального типорозміру в разі його успішного гасіння. Показник вогнегасної здатності $\left(Q_{A}\right)$ водної вогнегасної речовини в разі успішного гасіння модельних вогнищ пожежі класу А визначається як відношення маси витраченої вогнегасної речовини $(\Delta M)$ до площі поверхні горіння модельного вогнища пожежі $(S)$ :

$$
Q_{A}=\frac{\Delta M}{S}
$$

Результати випробувань наведено в табл. 2.

\begin{tabular}{|c|c|c|c|c|c|}
\hline $\begin{array}{c}\text { Водна вогне- } \\
\text { гасна речови- } \\
\text { на (ВВР) }\end{array}$ & $\begin{array}{c}\text { Позна- } \\
\text { чення } \\
\text { модель- } \\
\text { ного } \\
\text { вогни- } \\
\text { ща по- } \\
\text { жежі } \\
\end{array}$ & \begin{tabular}{|c|} 
Маса, \\
витра- \\
чена на \\
гасіння \\
ВВР \\
$(\Delta M)$, \\
кг \\
\end{tabular} & $\begin{array}{l}\text { Резуль- } \\
\text { тат га- } \\
\text { сіння }\end{array}$ & \begin{tabular}{|c|} 
Показ- \\
ник вог- \\
негасної \\
здатнос- \\
ті ВВР \\
$\left(Q_{A}\right)$ \\
$\kappa \Gamma / \mathrm{M}^{2}$ \\
\end{tabular} & Примітка \\
\hline $\begin{array}{c}6 \% \text { піноут- } \\
\text { ворюва- } \\
\text { ча S. F. Р. M., } \\
\text { вода - решта }\end{array}$ & $2 \mathrm{~A}$ & 8,9 & $\begin{array}{l}\text { пога- } \\
\text { шено }\end{array}$ & 0,93 & \begin{tabular}{|c} 
після пов- \\
торного \\
підпалю- \\
вання вог- \\
нище горі- \\
ло \\
\end{tabular} \\
\hline $\begin{array}{c}6 \% \text { піноут- } \\
\text { ворюва- } \\
\text { ча S. F. P. M., } \\
\text { вода - решта }\end{array}$ & $3 \mathrm{~A}$ & 8,9 & $\begin{array}{c}\text { не по- } \\
\text { гашено }\end{array}$ & - & प \\
\hline ФСГ-2M & $3 \mathrm{~A}$ & 7,8 & $\begin{array}{l}\text { пога- } \\
\text { шено }\end{array}$ & 0,55 & $\begin{array}{c}\text { на поверхні } \\
\text { звуглених } \\
\text { брусків } \\
\text { спостеріга- } \\
\text { ли наяв- } \\
\text { ність плів- } \\
\text { ки. Після } \\
\text { повторного } \\
\text { підпалю- } \\
\text { вання вог- } \\
\text { нище не за- } \\
\text { горілось }\end{array}$ \\
\hline
\end{tabular}

Табл. 2. Результати досліджень вогнегасної здатності водних вогнегасних речовин щодо гасіння модельних вогнищ класу А з використанням вогнегасника ВВШ-9

Як видно $з$ даних табл. 2, використовуючи заряд $6 \%$ водного розчину піноутворювача S. F. Р. М., максимально можливо погасити тільки модельне вогнище $2 \mathrm{~A}$, натомість зарядом ВВБЗР ФСГ-2М вдається впевнено погасити модельне вогнище 3А, тому показник вогнегасної здатності цих ВВР становить $0,93 \mathrm{\kappa r} / \mathrm{m}^{2}$ та 0,55 кг/м², відповідно. Окрім цього, фактично, під час намагання повторно підпалити модельне вогнище $3 \mathrm{~A}$, після його гасіння із застосуванням ВВБЗР ФСГ-2М, використовуючи таку саму кількість бензину А-76 (за методикою), повторного загоряння не відбулось, що свідчить про ймовірне модифікування шару коксу антипіреном. Надалі зазначене явище досліджували методами термогравіметрії. Для досліджень взяли зразок вугілля 3 модельного вогнища $2 \mathrm{~A}$, яке було погашене зарядом $6 \%$ водного розчину піноутворювача S. F. Р. М., та зразок вугілля з модельного вогнище $3 \mathrm{~A}$, яке було погашене зарядом ВВБЗР ФСГ-2М. Дослідження вказали на наявність вираженого ендотермічного ефекту в діапазоні температур від $150{ }^{\circ} \mathrm{C}$ до $350{ }^{\circ} \mathrm{C}$. Отже, можна стверджувати, що завдяки зазначеному ендотермічному ефекту на поверхні звугленої деревини (під час застосу- 
вання для гасіння ВВБЗР ФСГ-2М) не залишається осередків тління (жару), що можуть ставати джерелами повторного займання деревини. Це додатково підтверджують тим, що внаслідок термічних досліджень 100 мг вугілля (під час його нагрівання від $20^{\circ} \mathrm{C}$ до $1000{ }^{\circ} \mathrm{C}$ ) залишкова маса зразку звичайного вугілля становила 5,5 мг, а модифікованого вугілля - 22,9 мг.

Висновок. Використання полігексаметиленгуанідингідрофосфата карбаміду (ПГМГФК) як базової сполуки для водної вогнегасної речовини $є$ перспективним напрямом у створенні речовин для гасіння пожеж на об'єктах, де пожежне навантаження сформовано целюлозовмісними матеріалами.

\section{Перелік використаних джерел}

Antonov, A. V., Borovikov, V. O., Orel, V. P., Zhartovskyi, V. M., \& Kovalyshyn, V. V. (2004). Vohnehasni rechovyny. Kyiv: Pozhinformtekhnika. 176 p. [In Ukrainian].

Baratov, A. N., \& Molchadskyi, Y. S. (2011). Horenye na pozhare. Moscow: VNYYPO. 503 p. [In Russian].

Bilkun, D. G., Dubkov, P. F., Moiseenko, V. M., \& Peshkov, V. V. (1983). Ognetushashhie svoistva vody s dobavkami vysokomolekuliarnykh i nizkomolekuliarnykh soedinenii. Pozharotushenie, 89-92. [In Russian].

Bilkun, D. G., Kazakov, M. V., Peshkov, V. V., \& Puzako, M. V. (1982). Tushenie drevesiny vodoi s nizkomolekuliarnymi dobavkami. Teoreticheskie $i$ eksperimentalnye voprosy pozharotusheniia, 99-105. [In Russian].

DSTU 3675-98 (1999). Pozhezhna tekhnika. Vohnehasnyky perenosni. Zahalni tekhnichni vymohy ta metody vyprobuvan.
EN 1772 (2000). Surface active agents - Determination of setting powder by immersion (ISO 8022:1990 modified).

Kireev, A. A., Zhernoklev, K. V., \& Savchenko, A. V. (2005). Perspektivnye napravleniia snizheniia ekonomicheskogo i ekologicheskogo ushherba pri tushenii pozharov v zhilom sektore. Naukovii visnik budivnitctva, 31, 295-299. [In Russian].

Kireev, O. O., \& Babenko, O. V. (2002). Obrruntuvannia viboru sistem dlia doslidzhennia iavishha geleutvorennia pri rozrobtci novikh ridinnikh zasobiv pozhezhogasinnia. Problemy pozharnoi bezopasnosti, 12, 107-110. [In Russian].

Moiseenko, M. V., \& Dubkov, P. F. (1982). Vliianie dobavok vysokomolekuliarnykh soedinenii na ognetushashhie $i$ ognezashhitnye svoistva vody. Teoreticheskie $i$ eksperimentalnye voprosy pozharotusheniia, 106-113. [In Russian].

Muresan, L., \& Caceu, S. (2010). Critical infrastructures protection a Romanian perspective. Risk and security in the global world. Summer school. Retrieved from: http://bsu.ase.ro/oldbsu/anexe/lectures2010/

NFPA (2011). 18A Standard on Water Additives for Fire Control and Vapor Mitigation.

Nyzhnyk, V. V., \& Nyzhnyk, T. Yu. (2009). Fizychna khimiia polimeriv. Kyiv: Fitosotsiotsentr. 424 p. [In Ukrainian].

Standardization Administration of China (2006). GB 15308-2006 Foam extinguishing agent

Standardization Administration of China. (2008). GB 17835-2008 Water-based extinguishing agent

Yang Liang (2015). Fire extinguishing agents and standardization (Beijing: Scientific and technical documentation press), (chapter 1, (pp. 64-68).

Zhartovskyi, S. V. (2012). Vodna vohnehasna rechovyna yak zasib pylopodavlennia. Hornospasatelnoe delo, 49, 148-157. [In Ukrainian].

С. В. Жартовский

Украинский научно-исследовательский институт гражданской защиты, г. Киев, Украина

\title{
ИСПОЛЬЗОВАНИЕ СОЛЕЙ ПОЛИГЕКСАМЕТИЛЕНГУАНИДИНА В СОСТАВАХ ВОДНЫХ ОГНЕТУШАЩИХ ВЕЩЕСТВ ДЛЯ ПРОТИВОПОЖАРНОЙ ЗАЩИТЫ ОБЪЕКТОВ ИЗ ЦЕЛЛЮЛОЗОСОДЕРЖАЩИХ МАТЕРИАЛОВ
}

\begin{abstract}
Обоснована актуальность создания составов экологически безопасных водных огнетушащих веществ для активной противопожарной защиты объектов. Определена особая уязвимость объектов с пожарной нагрузкой, сформированной за счет целлюлозосодержащих материалов (древесины, тканей, бумаги, камыша и др.), поскольку они способны загораться даже от малокалорийных источников. На основе анализа практики разработки водных огнетушащих веществ определена перспективность добавления к воде разных ингредиентов для улучшения ее огнетушащих свойств, в частности для придания ингибирующих свойств. Определено, что позитивный опыт от использования солей полигексаметиленгуанидина в составах водных огнебиозащитных веществ для пассивной огнезащиты целлюлозосодержащих материалов целесообразно использовать и при разработке составов водных огнетушащих веществ для активной противопожарной защиты объектов. Экспериментальными исследованиями по стандартным методикам показано, что добавление к воде комплексного соединения полигексаметиленгуанидингидрофосфата карбамида в концентрации до 3 \% приводит к увеличению дальности струи водного огнетушителя BВ-9 не меньше чем на $10 \%$, при этом время выброса огнетушащего вещества из огнетушителя и время тушения модельного очага пожара $1 \mathrm{~A}$ сокращается не меньше чем на 15 \%. По оригинальным методикам определено, что использование водного огнетушащего вещества ФСГ-2М при тушении модельных очагов пожара класса А почти в 5 раз эффективнее в сравнении с водой, а при тушении модельных очагов пожара класса В - более чем в 3 раза. Полигонными испытаниями и лабораторными исследованиями раскрыт феномен невозможного повторного воспламенения пожарной нагрузки, сформированной древесиной, при использовании для тушения вещества ФСГ-2М.
\end{abstract}

Ключевые слова: водные огнебиозащитные вещества; активная противопожарная защита.

S. V. Zhartovskyi

Ukrainian Scientific Research Institute of Civil Defense, Kyiv, Ukraine

\section{THE USE OF POLYHEXAMETHYLENEGUANIDINE SALTS IN THE FORMULATIONS OF WATER-BASED FIRE-EXTINGUISHING AGENTS FOR FIRE SAFETY OF OBJECTS MADE OF CELLULOSE-CONTAINING MATERIALS}

The authors have emphasized the importance of creating formulations of environmentally safe water-based fire-extinguishing agents for active fire protection of objects that belong to the national critical infrastructures, the functional failure or damage of which cause the most serious consequences for the social and economic spheres of the state, and will have a negative impact on its defense capability level and the national security. The analysis of the statistics data determined the special vulnerability of the objects with the fire load, formed due to cellulose-containing materials (wood, cloth, paper, bulrush, etc.), since they can inflame even from low-calorie sources. On the basis of analysis of practice of developing water-based fire-extinguishing agents, we found promising to add different ingredients to water for improvement of its fire-extinguishing effect, in particular, for adding inhibiting properties to it. 
The authors have defined that it is advisable to use the positive experience of applying polyhexamethyleneguanidine salts in the formulations of water-based biological flame retardants for passive fire protection of cellulose-containing materials also for the development of formulations of water-based fire-extinguishing agents for active fire protection of objects. Experimental investigations according to the standard methods showed that adding the complex composition of carbamide polyhexamethyleneguanidine hydrophosphate to water in concentration of up to $3 \%$ results in the increase of the throwing range of the water-based fire extinguisher BB-9 at least by $10 \%$, with this the time of throwing fire-extinguishing agent from the fire extinguisher and the time of extinguishing the model fire $1 \mathrm{~A}$ is reduced at least by $15 \%$. The original method was applied, which consists of determining the fire-extinguishing efficiency of the studied water-based fire-extinguishing agents by means of determining their mass, which is required to be supplied, under the same conditions, for extinguishing a fire of A class with finelydivided sprays. It was determined that application of FSG-2M for extinguishing of model fires of A class is almost 5 times more efficient compared to water. The results of investigation of fire-fighting efficiency of water-based agents for extinguishing fires of $\mathrm{B}$ class were presented. Finally, the authors have determined that the use of FSG-2M agent for extinguishing of model fires of B class was more than 3 times more efficient compared to water. Field and laboratory tests revealed the phenomenon of making the repeated inflammation of the fire load, formed by wood, impossible with application of FSG-2M agent for fire extinguishing.

Keywords: water-based fire-extinguishing agents; active fire protection. 